\title{
Immunochemical Properties of Recombinant Ompf Porin from Outer Membrane of Yersinia pseudotuberculosis
}

\author{
Olga Portnyagina, Olga Sidorova, Valentina Khomenko, \\ Olga Novikova, Marina Issaeva and Tamara Solov'eva \\ Pacific Institute of Bioorganic Chemistry, Far-Eastern Branch, \\ The Russian Academy of Sciences, \\ Russia
}

\section{Introduction}

Porins from outer membranes (OM) of Gram-negative bacteria exist in intact membranes as homotrimers forming water-filled pores or channels that provide low-molecular compounds transportation. Surface localization of the porins and their structural peculiarities determine multiplicity of their functions except for the transport one. On the one hand, porins are targets for the host immune system. As the targets they activate factors of the organism fast protection and are involved in the formation of specific immune response. On the other hand, porins serve as the factors of pathogenesis and virulence inhibiting the first stage of the host immune system and providing survival of a pathogen in macroorganism. Porins are species- and genus-specific antigens of Gram-negative bacteria and belong to the highly immunogenic OM components. The antibodies against the porins are found in blood sera both after vaccination and after natural development of infection.

Many researchers have confirmed the existence of two types of porin antigenic determinants. The first type of the determinants is linear (at the level of the primary structure of the protein) and the second one is conformational (or discontinuous) formed at the higher levels of the protein structure. According to some authors, the majority of the conformational determinants (Ranling, et al, 1995) are destroyed during the dissociation of porin trimers under the different denaturing conditions, especially temperature (Lupi et al, 1980). Most the antigenic determinants are believed to be located in the outer loops with unordered structure. In contrast, epitopes located in the transmembrane protein sites are conservative and have a high degree of homology in porins of Enterobacteriaceae microorganisms (Singh et al, 1996).

The immune response to OM proteins (including porins) has a number of features, namely, the high level of antibodies (as a result both of artificial immunization and of the natural infection development) and duration of circulation of antibodies (immunological memory). It should be noted that in the organism of experimental animals (mice, rabbits, rats, and monkeys) antibodies to the OM porins are formed independently of a mode of the antigen 
injected: isolated proteins, whole cells or the cell wall fragments. As shown, antibodies to porin dominated in the monkey infected and pseudotuberculosis patients' sera but not in small laboratory animal sera after experimental infection (Vostrikova et al, 2000).

In the case of antibodies against recombinant porins, both in trimeric and in monomeric forms of the proteins were shown to be highly immunogenic in rabbits, even without adjuvants (Elkins et al, 1994), as well as they stimulated the production of bactericidal and diagnostic IgG antibodies in immune stimulating complex (iscom) or vesicles containing components of the OM (Peeters et al, 1999; Wright et al, 2002). In some cases immunization with recombinant porin was shown to induce not only CD4 + T-cells proliferation but the production of IL-12 as well (Shaw et al, 2002).

Since immunization with pore-forming proteins of bacterial OM leads to the formation of specific antibodies, activates the cellular immune system response and causes no adverse reactions, the porins are considered to be the most promising candidates for vaccines of new generation (Supotnitsky, 1996).

The bacteria of Yersinia species belong to the microorganisms that cause intestinal infections in humans and animals. According to the World Health Organization data these diseases are revealed worldwide and more frequently in the economically developed countries where is a wide network of the centralized foodstuffs supply. At the present special interest to the problem of yersiniosis is connected with the immunopathologies, so-called secondary yersiniosis (or second-hearth) forms (arthritis, myocardit, neuralgia, collagenosis) caused in patients by Yersinia infection. The etiology of such immunopathologies is not determined in practice because of the absence of specific diagnostic methods (Portnyagina et al, 2010).

Besides, there are no methods of specific protection from the infections caused by pathogenic Yersinia. Therefore, the creation of polyvalent vaccine protecting from plague, intestinal yersiniosis, and pseudotuberculosis is the urgent task. The high degree of homology of Yersinia porin primary structures (Guzev et al, 2005; Likhatskaya et al, 2005; Issaeva et al, 2003) is a basis for creation of the vaccine preparations that will protect against all infections caused by pathogenic Yersinia species (Antonets et al, 2007; Portnyagina et al, 2010).

In this study we have investigated the capacity of the pore-forming recombinant protein from OM of $Y$. pseudotuberculosis to induce immune response in CBA mice. Immunization with the recombinant protein (with and without adjuvants) resulted in IgG antibodies. High-avidity immune serum was obtained as a result of the tree-time immunization. Bactericidal activity of peritoneal macrophages from mice immunized with recombinant protein was significantly higher than that of intact murine macrophages. The use of the recombinant porin instead of native one as the antigen in ELISA for the diagnostics of acute and secondary-hearth forms of pseudotuberculosis does not reduce the efficiency of detection of specific antibodies in the sera of patients. Obtaining of the Y. pseudotuberculosis mutant forms of recombinant $\mathrm{OmpF}$ porin with outer loops deletions is of particular interest. The study of the relationship between the structure, function, and antigenic properties of mutant proteins will increase the fundamental understanding of the properties of porins and open up new opportunities for the development of highly efficient and specific means for diagnostics and prevention of diseases caused by Yersinia. 


\section{Obtaining of recombinant porin}

\subsection{Construction of recombinant plasmid with mature Y. pseudotuberculosis OmpF porin sequence}

The $o m p F$ gene lacking sequence for the signal peptide was amplified from genomic DNA of the Y. pseudotuberculosis 3260 strain using the primer pair of FYm/NdeI (5 TCGCATATGGCTGAAATCTACAACAAAG- 3') and RY/BamHI (5'GGATCCTTAGAACTGATAAACCAAGCC- $3^{`}$ ). GGATCCTTAGAACTGATAAACCAAGCC3) was used in the reaction. The primers were designed with Primer Premier 3. The PCR procedure was carried out in a reaction volume of $100 \mu \mathrm{l}$ containing $1.5 \mathrm{mM} \mathrm{MgCl}_{2}$, dNTP (200 $\mu \mathrm{M}$ of each), direct and reverse primers $(0,5 \mu \mathrm{M}$ of each), $2.5 \mathrm{U}$ AmpliTaq DNA polymerase (Applied Biosystems), and DNA template (50 ng). The thermal cycling profile was as follows: (1) preliminary DNA denaturion at $95^{\circ} \mathrm{C}$ for $5 \mathrm{~min}$; (2) 35 cycles, denaturion at $94^{\circ} \mathrm{C}$ for $20 \mathrm{sec}$, annealing at $55^{\circ} \mathrm{C}$ for $30 \mathrm{sec}$, and polymerization reaction at $72^{\circ} \mathrm{C}$ for 1 min $10 \mathrm{sec}$; and (3) final extension step of $72^{\circ} \mathrm{C}$ for $5 \mathrm{~min}$. The amplicons were analyzed by electrophoresis in 1\% agarose gel. The resulting PCR fragment was purified, digested by restriction endonucleases NdeI and BamHI (Fermentas), and cloned into expression vector pET41a (Novagen) by the respective restriction sites. The recombinant clones of E. coli DH5 $\square$ strain were selected in the presence of kanamycin $(50 \mathrm{mg} / \mathrm{ml})$, and recombinant plasmids were verified by DNA sequencing on a ABI PRISM 310 Genetic Analyzer (Applied Biosystems) using universal T7 promotor and T7 terminator primers. The recombinant expression plasmid (pET41-m55) was transformed into BL21 (DE3) (Invitrogen), tand selected in the presence of kanamycin $(50 \mathrm{mg} / \mathrm{ml})$. The positive clones were used for largescale culturing experiments.

\subsubsection{Isolation and purification of recombinant protein}

The resulting pET-m55 plasmid with an intact reading frame was used for transformation of E. coli BL21 (DE3) strain. Selection of the recombinant clones was carried out in the presence of kanamycin $(50 \mathrm{mg} / \mathrm{ml})$. An empty vector was used as a control. Immunoblot analysis showed that lysate of transformed E.coli BL21 (DE3) strain contained a protein with the mobility close to $40 \mathrm{kDa}$. It interacted with specific antibodies against thermostable porin monomer (OmpF-m) of the pseudotuberculosis microorganisms. At the same time, this protein was not detected in the non-transformed cells lysate (Fig.1a). Based on these data, we concluded that the protein obtained corresponded to the Y.pseudotuberculosis porin. The E. coli cells transformed were cultured in 1.01 of the LB medium containing $100 \mathrm{mg} / \mathrm{l}$ kanamycin at $37^{\circ} \mathrm{C}$ for $4-5 \mathrm{~h}$ until obtaining suspension with optical density of $\sim 0.6$ at 600 $\mathrm{nm}$. One mM IPTG was then added to the medium and the cells were cultured again for another $4-5 \mathrm{~h}$. The cells were precipitated by centrifugation at $10000 \mathrm{~g}$ for $15 \mathrm{~min}$; the precipitate $(5 \mathrm{~g})$ was resuspended in $15 \mathrm{ml}$ of $50 \mathrm{mM}$ Tris- $\mathrm{HCl}, \mathrm{pH} 8.0$, containing $1 \mathrm{mM}$ EDTA and $100 \mathrm{mM} \mathrm{NaCl}$ (TEN buffer). A solution of PMSF $(40 \mu \mathrm{l}, 100 \mathrm{mM}$ stock solution in isopropanol) and lysozyme $(4 \mathrm{mg})$ were added to the suspension. The mixture was stirred at room temperature for $30 \mathrm{~min}$, after that DOC $(25 \mathrm{mg})$ was added and the mixture was kept for $20 \mathrm{~min}$ on a water bath at $37^{\circ} \mathrm{C}$. DNase $(30 \mu \mathrm{l}, 1 \mathrm{mg} / \mathrm{ml}$ stock solution) was added, the mixture was stirred at room temperature until obtaining of a non-viscous solution. The mixture was then centrifuged at $12000 \mathrm{~g}$ for $20 \mathrm{~min}$ at $4^{\circ} \mathrm{C}$. The precipitate of inclusion bodies (IB) was washed twice then urea and PMSF up to final concentrations of $8 \mathrm{M}$ and $0.1 \mathrm{mM}$, respectively. The mixture was sonicated at $44 \mathrm{MHz}$ for $10 \mathrm{~min}$ with intervals of $1 \mathrm{~min}$. The 
insoluble precipitate was separated by centrifugation at $12000 \mathrm{~g}$ for $10 \mathrm{~min}$ at $4^{\circ} \mathrm{C}$. Based on Western-blotting analysis and SDS-PAGE (Fig. 1a) data, we concluded that the transformed E. coli cells expressed the porin from pseudotuberculosis pathogen. IB obtained by this method contained a major protein with the mobility correspondent to that of the Y. pseudotuberculosis porin in monomeric form (OmpF-m), and a small amount of lower molecular mass proteins. Gel staining with silver ions showed the lack of lipopolysaccharide (LPS) in the IB.

The protein concentration of IB was determined spectrophotometrically. The refolded recombinant porin was obtained using exhaustive dialysis and different types of chromatography in the presence of various detergents. The ionic detergent SDS is widely used for solubilization of membrane proteins but its application for protein refolding is known to prevent the formation of stable porin oligomers (Arockiasamy et al, 2004). Nevertheless, considering the high stability of Y. pseudotuberculosis porin to action of SDS (Novikova et al, 1989), we chose the gel chromatography on Sephacryl S-300 (Pharmacia, Sweden) in the presence of SDS for refolding of the recombinant porin. The protein solution was diluted at a ratio of $1: 2$ with TEN buffer containing $4 \%$ SDS, sonicated on ice at $44 \mathrm{MHz}$ for $10 \mathrm{~min}$, and loaded onto a Sephacryl S-300 column $(2.0 \times 70.0 \mathrm{~cm})$ equilibrated with $100 \mathrm{mM}$ Tris-HCl buffer (pH 8.0) containing $10 \mathrm{mM}$ EDTA, $200 \mathrm{mM} \mathrm{NaCl}, 0.1 \%$ SDS, and $0.02 \%$ sodium azide. The elution rate was $10 \mathrm{ml} / \mathrm{h}$. According to the SDS-PAGE, protein fractions obtained by chromatography contained only the recombinant porin in monomer form (RP) (Fig. 1b).

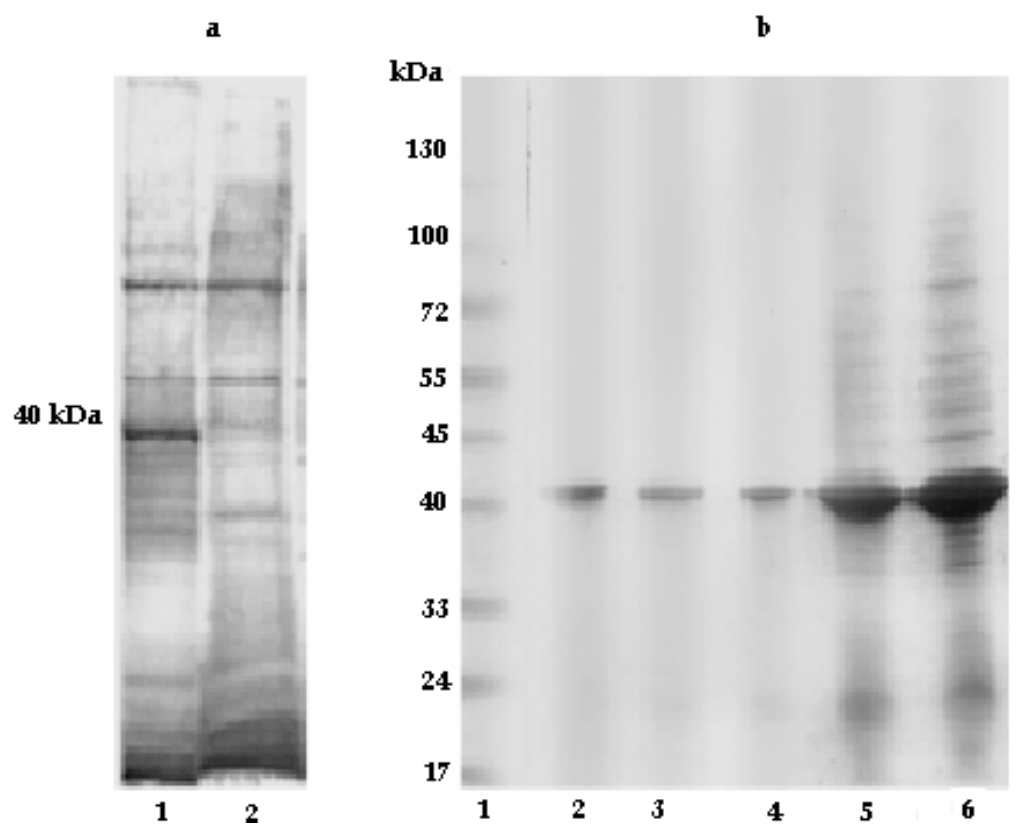

SDS-PAGE of protein fractions (b): 1 - standard proteins; 2 - RP heated at $100^{\circ} \mathrm{C} ; 3$ - RP; 4 - OmpF-m; 5 - IB in $8 \mathrm{M}$ urea; 6 - IB heated at $100^{\circ} \mathrm{C}$.

Fig. 1. Western-blotting of the protein fractions with rabbit antibodies obtained as a result of Y. pseudotuberculosis OmpF-m immunization (a): 1 - lysate of transformed E.coli cells; 2 lysate of non-transformed E.coli cells. 
The results of ELISA showed that the IB isolated from the transformed E. coli cells did not contain the E. coli OM OmpF porin (Fig. 2).

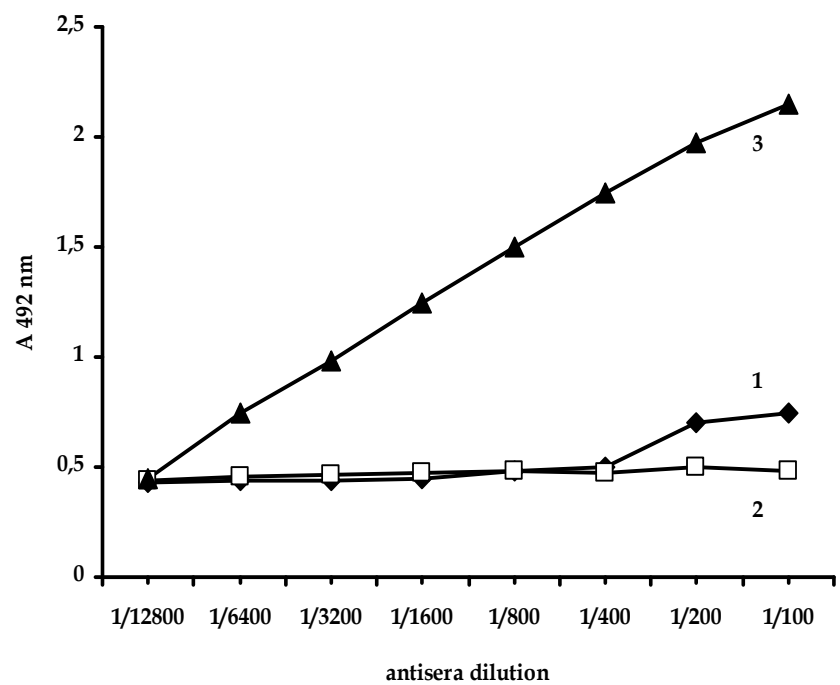

Fig. 2. ELISA of interaction of antiserum obtained after rabbits immunization with OmpF-m from Y. rseudotuberculosis OM with: RP (3); IB derived from E.coli cells without insertion into the plasmid (2), OmpF porin from E.coli OM (1).

\subsubsection{Site-directed mutagenesis of the gene OmpF porin}

Site-directed mutagenesis of recombinant plasmid pET41a (+)-m55 carrying ompF gene was performed to obtain mutant proteins with deletions of loops L1(del 1), L6 (del 6), and L8 (del 8). This plasmid was constructed previously for the expression of the mature OmpF porin. To obtain the original methylated DNA, the plasmid was passed through E. coli XL-1 Blue strain. Mutagenic oligonucleotide primers (Table 1) were designed to remove the external loops L1, L6, and L8 (the primers did not contain correspondent sites). Site-directed mutagenesis was performed using polymerase Pfu Ultra II (Stratagene, USA) according to the algorithm proposed in (Wang \& Malcolm, 1999).

\begin{tabular}{|l|l|c|}
\hline Name & \multicolumn{1}{|c|}{ Sequence (5`-3`) } & Appointment \\
\hline T7 prom & TAATACGACTCACTATAGGG & \multirow{2}{*}{ sequencing primer } \\
\hline T7 term & GCTAGTTATTGCTCAGCGG & \multirow{2}{*}{ Loop deletion L1 } \\
\hline Del_L1_for & GTCACTCTTTCTCCGATGGCGACAAGTC & \multirow{2}{*}{ Loop deletion L6 } \\
\cline { 1 - 2 } Del_L1_rev & GACTTGTCGCCATCGGAGAAAGAGTGAC & \multirow{2}{*}{ Loop deletion L8 } \\
\cline { 1 - 2 } Del_L6_for & CTCAGAACCTGACTGCGAACAAGACTCG & \\
\cline { 1 - 2 } Del_L6_rev & CGAGTCTTGTTCGCAGTCAGGTTCTGAG &
\end{tabular}

Table 1. Characteristics of primers 
The mixture of mutant plasmids resulted after amplification and initial mixture were treated with restriction endonuclease DpnI (Fermentas, Lithuania) for the cleavage of methylated and half-methylated plasmid DNA. This mixture was then used for transforming the cells of E. coli Rosetta strain. To select colonies containing "functional" mutant plasmids, the analytical expression of proteins was performed in $30 \mathrm{ml}$ of the LB medium. Results of the expression were assessed by SDS-PAGE (Fig. 3). Colonies 1 and 2 as well as colonies 6 and 8-12 presumably expressing the mutant proteins were selected for the amplification and sequencing of ompF gene. PCR amplification was performed using GoTaq polymerase (Promega, USA). PCR fragments were purified using DNA Extraction commercial Kit (Fermentas, Lithuania) and were sequenced using primers T7prom/T7term (Table 1) on an automatized DNA analyzer 3130XL (Applied Biosystems, USA). According to the results of sequencing we selected plasmids containing the deletions of the external loops and maintaining the integrity of the protein encoding sequence of ompF. Thus, it was found that the "functional" mutant colonies selected produced a target protein.

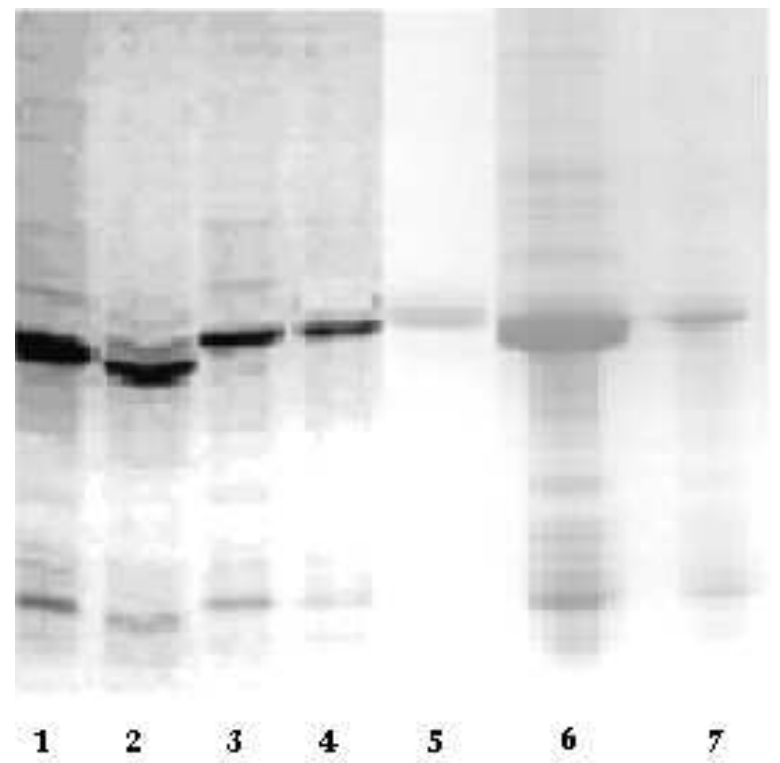

Fig. 3. SDS-PAGE of mutant proteins: 1, 2 - del 1 (heated at $100^{\circ} \mathrm{C}$ and unheated, respectively); 3,4 - del 6 (unheated and heated at $100^{\circ} \mathrm{C}$, respectively), 5 - RP (control, expression in strain BL21 (DE3) E. coli); 6,7 - del 8 (unheated and heated at $100^{\circ} \mathrm{C}$, respectively).

\subsubsection{Isolation and purification of recombinant mutant forms of the OmpF porin $\mathrm{Y}$. pseudotuberculosi}

Isolation of proteins with deletions of loops L1, L6, and L8 (samples del 1, del 6, and del 8) was performed according to the procedure developed for RP, except that in the case of mutant proteins we used double amount of lysozyme and DNase. We also isolated fullsized RP as a control. IB containing the mutant porin from urea was purified by exhaustive 
dialysis (within 4 days). As a result we obtained targeted mutant proteins in monomeric form. According to the SDS-PAGE their electrophoretic mobility coincided with the mobility of RP. The results of refolding of the mutant porin monomers were confirmed by Westernblotting with rabbit antibodies against the native OmpF-m and with murine antibodies against full-sized RP (Fig. 4).

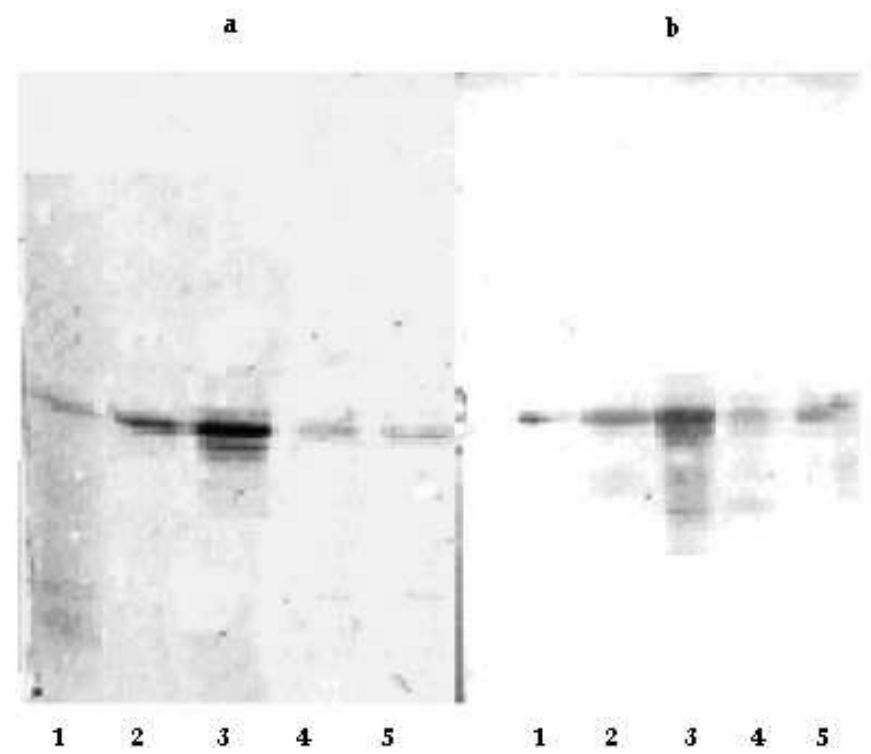

Fig. 4. Western-blotting of protein fractions:

1 - del 1; 2 - del 6; 3 - OmpF-m; 4 - del 8; 5 - RP with rabbit antibodies obtained by immunization of OmpF-m (a);

1 - del 1; 2 - del 6; 3 - RP; 4 - del 8; 5 - native OmpF-m with murine antibodies obtained by immunization of RP (b).

\subsection{Antigenic structure of recombinant porins}

The antigenic structure of recombinant and mutant proteins was characterized by ELISA. The RP was shown to interact with specific antibodies against OmpF-m. However, complete binding of specific antibodies with the antigen was not observed. The results confirmed that antigen structure of RP only partially corresponded to that of native porin monomer (Fig. 5). Quite possible, the linear antigen determinants (probably formed at the level of primary and/or secondary porin structure) served as common parts of RP and native porin (Portnyagina et al, 1999). At the same time discontinuous (or conformational) antigen determinants (forming by closing in some parts of protein amino acid sequence during assembling 3D protein structure) were absent or were not properly formed.

The mutant porins with the outer loop deletions were found to interact with specific antibodies against the full-sized RP and native OmpF-m (Fig. 6). The results of binding of mutant proteins and RP with antiserum to the latter are similar (Fig. 6a). This suggests that the regions of porin sequence corresponding to the outer loops L8, L1, and L6 do not 
participate in the formation of the RP antigenic determinants. A similar pattern was observed in the interaction of mutant porins del 1 and del 6 with antibodies to the OmpF-m (Fig. 6b). The exception was the del 8, which reacted with these antibodies $30-40 \%$ less efficiently.

It can be assumed that the structure of antigenic determinants of recombinant and native porin monomers has partial coincedence at the region of incomplete forming (in the case of recombinant protein) conformational determinants. This result may also reflect the fact that region of protein sequence corresponding to loop L8 are part of the conformational epitopes of the OmpF-m. Besides, this result was consistent with the antigenic determinants calculated theoretically using various computer programs (ProPred, SYFPEITHI, and RANKPEP) and allowed us to predict the regions of interaction with the T-receptors on the surface of human lymphocytes. According the data obtained by this software it was found that less than $20 \%$ of the total number of calculated peptides coincided with the porin external loops areas and the significant part of the latter occured in the loop 8 (Portnyagina et al, 2010).

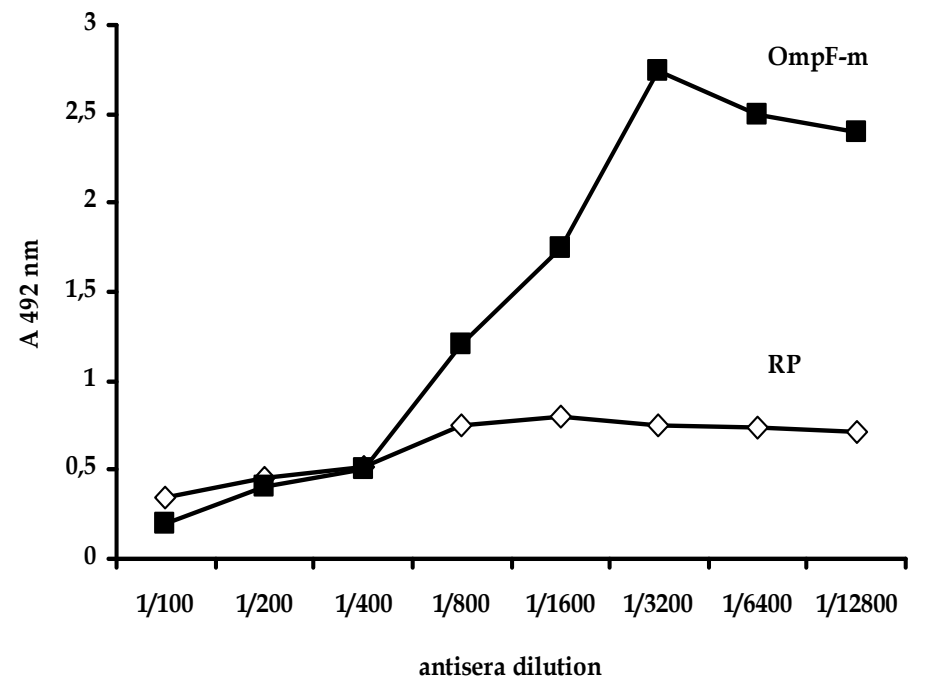

Fig. 5. ELISA of binding of rabbit antisera against OmpF-m with homologous antigen and RP.

\section{$2.3 \mathrm{Immunogenic}$ properties of recombinant porins}

\subsubsection{Obtaining of immune sera}

Specific sera to RP were obtained as a result of CBA mice immunization with RP in saline solution mixed with Freund's adjuvant and in detergent solutions. Protein was injected intraperitoneally (100 $\mu \mathrm{g}$ per mouse) three times with intervals of 7 days. The mice of the first group were immunized with purified RP in saline solution. The mice of the second group were immunized by RP mixed with Freund's complete adjuvant (RP/Fr) in ratio 1:1 $(\mathrm{v} / \mathrm{v})$, the mice of the third group were immunized by RP in $0.05 \%$ octyl- $\beta$-Dglucopyranoside (RP/OG) and the mice of the fourth group were immunized by RP in $0.1 \%$ 

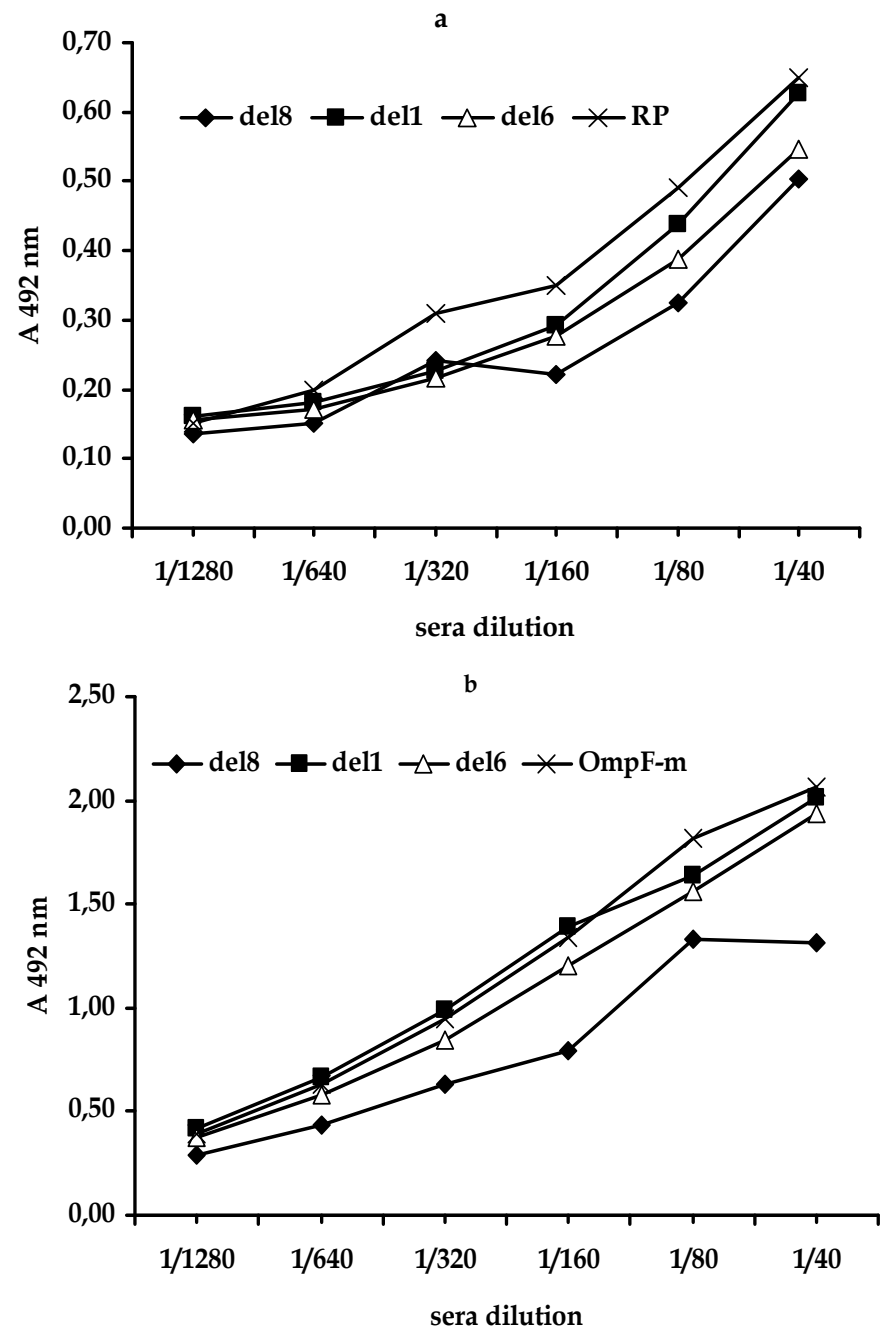

Fig. 6. ELISA of interaction of mutant porins with specific antibodies to: RP (a) and OmpF$\mathrm{m}(\mathrm{b})$.

Zwiterrgent $3-14(\mathrm{RP} / \mathrm{Zw})$. To obtain the control serum, we immunized the mice three times with saline solution. Blood sampling was carried out by decapitation of the mice a week after the last immunization. To study the sera obtained, we used indirect ELISA. As second antibodies we used rabbit antibodies against mouse IgG labeled with peroxidase (production of Gamaleya Research Institute of Epidemiology and Microbiology, Moscow). Avidity index (AI) of the sera obtained (which described the ability of a heterogeneous antibodies mixture to bind the antigen and depended on the specificity of the antigen/antibody interaction) was determined by ELISA as described in (Vermot et al, 2002). To remove the low-avidity antibodies, we used $6 \mathrm{M}$ urea solution as a reagent (AppliChem, Germany). 
Using ELISA, we determined antibody titers of the immune sera obtained (-lg) (Table 2). It was shown that the serum with the highest titers was obtained by animal immunization with $\mathrm{RP} / \mathrm{Fr}$. The titer values of the serum obtained by the immunization with $\mathrm{RP} / \mathrm{Zw} 3-14$ and RP were 1-2 dilution lower than serum titer level of RP/Fr. The least amount of specific antibodies in the serum was obtained as a result of animal immunization with RP/OG. We found that sera obtained by immunization with all RP pattern had the high value of IA (Table 2). Thus, the low level of antibodies against recombinant porin obtained by immunization of mice with RP/OG did not affect the avidity of these antibodies. A similar result was observed earlier in (Vermot et al, 2002), where the avidity of the serum obtained by animal immunization with Neisseria porin was shown to be virtually independent of the level of specific antibodies in this serum.

\begin{tabular}{|l|l|l|}
\hline Sample & AT $(-\lg )$ & AI $(\%)$ \\
\hline RP & 2,5 & 85 \\
\hline RP/Fr & 3,55 & 89 \\
\hline RP/Zw & 2,8 & 82 \\
\hline RP/OG & 1,9 & 79 \\
\hline
\end{tabular}

Table 2. Antibody titers (AT) and avidity index (AI) in the antisera obtained by immunization of mice with different patterns of RP.

\subsubsection{Stimulation of murine macrophages by recombinant porin}

One of the most important indicators of the host's immune system is the level of functional activity of mononuclear phagocytic cells. Macrophages are the first cells interacting with alien antigens during the infection development and playing an important role in antimicrobial host defense. Activation of macrophages is accompanied by oxygendependent metabolic "explosion" with the production of highly unstable products of oxygen reduction including hydrogen peroxide. Hydrogen peroxide is the main substrate for the enzyme myeloperoxidase - an important component of the antimicrobial activity of the phagocytic system. Myeloperoxidase catalyzes the reaction of the formation of hydrogen peroxide in the presence of chloride anions (Ruleva et al, 2007).. Thus, the change in the amount of myeloperoxidase is a measure of the functional status of phagocytic cells (Menshikova et al, 1994).

Y. pseudotuberculosis is known to interact with macrophages and inhibit the activity of oxygen-dependent microbicidal system by supressing enzyme activity during natural infection (Somov et al, 1990). Increase of activity of enzymes involved in synthesis of active oxygen metabolites, including myeloperoxidase, was observed in peritoneal neutrophils infected by Y.pseudotuberculosis cells in vitro. It was the evidence of the development of cell protective reaction in response to the bacterial invasion. In our work we studied the effect of $\mathrm{RP}$ on the functional state of macrophages from peritoneal exudate of mice (intact and immunized with RP) in vivo and in vitro and estimated the amount of myeloperoxidase synthesized by phagocytes in response to stimulation by Y.pseudotuberculosis cells.

Cells of peritoneal exudate were obtained by washing the abdominal cavity of mice with 5 $\mathrm{ml}$ of chilled Hanks balanced solution containing $2 \mathrm{ml}$ of heparin. The amount of cells was counted and their viability was determined by trypan blue test (Merck, Germany). Cell suspension $(50 \mu \mathrm{l})$ was added into the 96-well plate wells and incubated for $2 \mathrm{~h}$ in an 
atmosphere of $5 \% \mathrm{CO}_{2}$ at $37^{\circ} \mathrm{C}$, the medium was then removed and the wells were washed with Hanks solution to remove the not adherent cells. To determine the effect of RP on macrophages in vitro, cells were pre-incubated with various concentrations of RP and antigen solution was removed after $1 \mathrm{~h}$. To determine the induced production (IP) of myeloperoxidase we added $20 \mu \mathrm{l}$ (per a well) of suspension containing a different amount of Y. pseudotuberculosis cells (strain 512, serovar IB) killed by autoclaving. To determine the spontaneous enzyme production (SP), saline solution $(20 \mu \mathrm{l})$ was added as control. The plates were incubated for $1 \mathrm{~h}$ at $37^{\circ} \mathrm{C}$, washed three times with Hanks solution, and $100 \mu \mathrm{l}$ (per a well) of phosphate-citrate buffer ( $\mathrm{pH} 5.0$ ) containing $0.04 \%$ of $o$-phenilendiamin and $0.003 \%$ of $\mathrm{H}_{2} \mathrm{O}_{2}$ were added. After 10 min the reaction was stopped by adding $100 \mu \mathrm{l}$ of $10 \%$ $\mathrm{H}_{2} \mathrm{SO}_{4}$. The amount of peroxidase was estimated by the optical density (OD) at $492 \mathrm{~nm}$. Stimulation index (IS) was calculated as the ratio of induced and spontaneous production of peroxidase: $\mathrm{IS}=\mathrm{PI} / \mathrm{SP}$.

It was established that immunization of mice with RP caused an increased production of myeloperoxidase (Fig. 7a). Increase of myeloperoxidase level indirectly characterizes oxygen-dependent killing of bacteria in phagocyte (complete phagocytosis), therefore it shows that the three-time immunization of mice with RP (100 $\mu \mathrm{g} /$ mouse) leads not only to the synthesis of specific antibodies but stimulates the enhancement of induced bactericidal activity of peritoneal macrophages as well. This result coincides with previous data that increased activity of macrophages is a result of experimental pseudotuberculosis infection (Timchenko et al, 1990) and immunization with the porin isolated (Portnyagina et al, 1999).

Experiment in vitro also showed that the addition of RP into system intact macrophage/Y. pseudotuberculosis cells enhanced the synthesis of myeloperoxidase in the monolayer of peritoneal macrophages and the amount of the enzyme depended on the dose of RP (Fig. 7b).

a

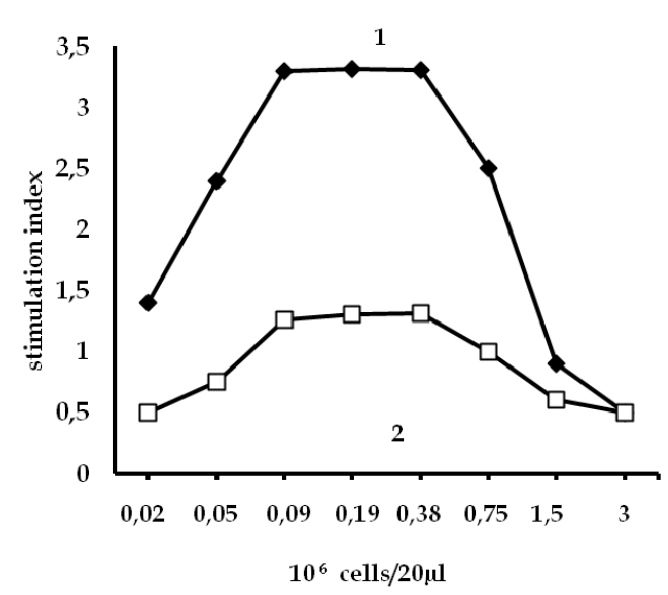

$\mathrm{b}$

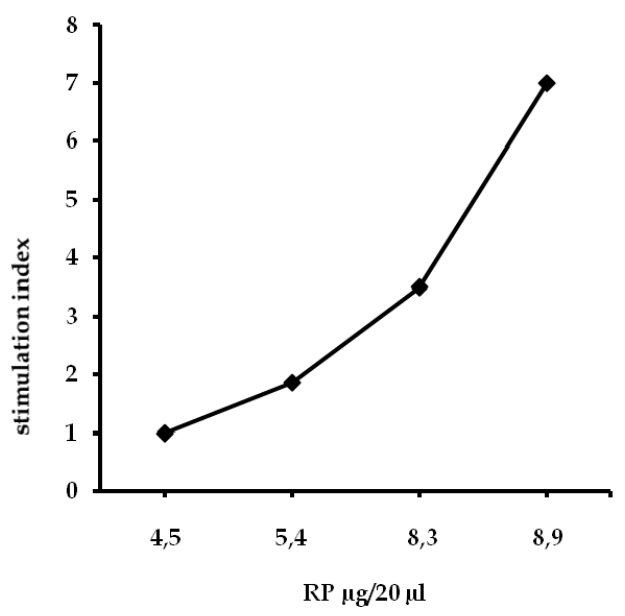

Fig. 7. Synthesis of myeloperoxidase in macrophages of immune (1) and non-immune (2) mice (a). The effect of RP on the synthesis of myeloperoxidase in non-immune macrophages of mice (b). 
In the cause of addition the antibodies against RP to the system of non-immune macrophages/Y. pseudotuberculosis cell, (Fig. 8) decrease of myeloperoxidase production by the phagocytes was observed. Probably, this is the consequence of interaction of the surface antigens of Y. pseudotuberculosis with the opsonic factors of serum (Somov et al, 1990), this effect is most typical for mice. In addition, specific antibodies to RP are supposed to block the adhesion receptors on the surface of bacterial cells since these receptors are the regions of the outer loops of the porin molecule (Plekhova et al, 2007). This leads to the decrease of the stimulatory effect of bacteria in relation to macrophages.

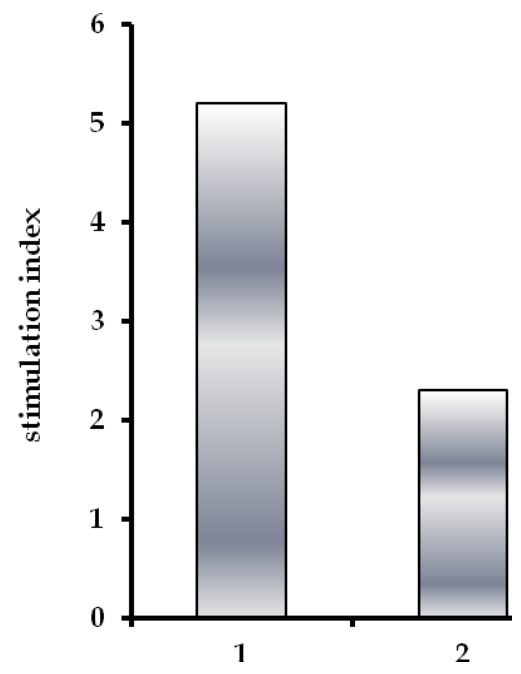

Fig. 8. Amount of peroxidase produced by macrophages of non-immune mice in the absence (1) and presence (2) antibodies to RP.

Thus, immunization with Y. pseudotuberculosis RP was found to stimulate the host's immediate protection factors by activating the oxygen-dependent bactericidal activity of phagocytes and initiating the development of humoral immune response. Consequently, the recombinant porin can be used as a component of vaccine preparations for effective protection against infection caused by Y.pseudotuberculosis.

\subsection{Recombinant porin as diagnostic antigen}

It is widely known that the use of recombinant proteins or synthetic peptides as components of diagnostic test systems can increase the sensitivity of the latter and exclude non-specific hyperdiagnostics. Using RP in ELISA kit developed by us earlier (Gordeets et al, 2000), sera of patients with acute intestinal pseudotuberculosis infection were analyzed. It was shown that specific antibodies in patients' sera (dilution 1:800) were detected by RP. Activity of RP as diagnostic antigen was found to be comparable to that of OmpF-m used in ELISA kit (Fig. 9a). A similar result confirming the specificity of this reaction was obtained by inhibiting the interaction of antigen (RP or OmpF-m) with the sera obtained from sick childs with an acute form of pseudotuberculosis. It was found that RP inhibits the binding reaction in 1.43 times more efficient compared to OmpF-m (the data are not shown). 


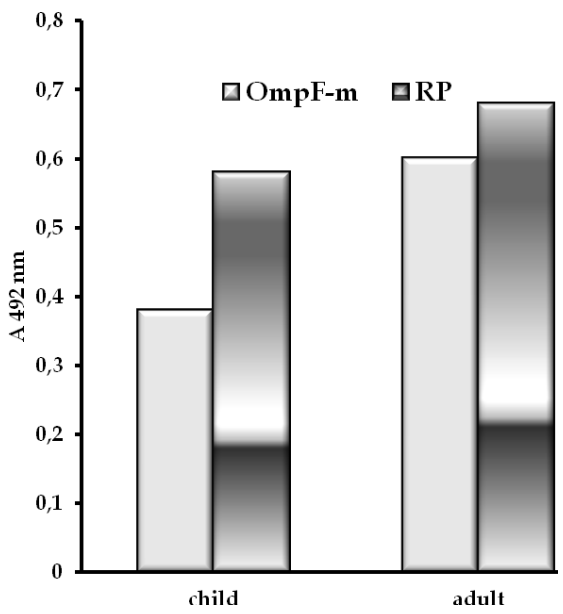

b

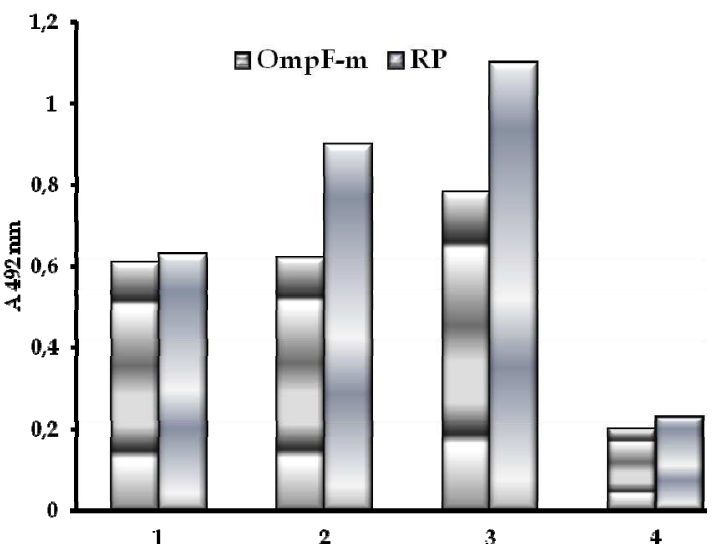

Fig. 9. ELISA of interaction of RP and OmpF-m antigens with specific antibodies in sera of: patients with acute intestinal pseudotuberculosis (a) and patients with secondary forms of pseudotuberculosis (b). 1,2 - sera of patients with symptoms of lesions of the peripheral nervous system, 3 - sera of patients with symptoms of lesions of the musculoskeletal apparatus, 4 - sera of healthy donors.

It is known that the secondary pseudotuberculosis forms are often accompanied by disorders of the cardiovascular and nervous systems, musculoskeletal system, urinary system, and gastrointestinal tract (Tseneva, 2006). To identify the yersiniosis etiology of diseases in patients with similar symptoms, the sera of patients with lesions of musculoskeletal system and peripheral nervous system were also analyzed. The specific antibodies to $Y$. rseudotuberculosis RP were detected in significant number of sera of both groups of patients, 40 and 17\%, respectively (Fig. 9b). RP was found to reveal the specific antibodies on the average 1.3 times more effective than OmpF-m. Perhaps, the greater 
efficiency of RP as a diagnostic antigen is a result of more correct assembly of porin spatial structure during RP refolding. Therefore, antigenic epitopes of RP are more corresponding to the conformational determinants of native protein structure than that of OmpF-m due to loss of a part of conformational determinants of OmpF-m during the isolation procedure (Haltia \& Freire, 1995).

In addition, recombinant porins with the external loops deletions were also found to interact with the antibodies in the serum of the patients with acute intestinal and second-hearth forms of pseudotuberculosis. However, their activity in case of acute pseudotuberculosis was much lower compared to the OmpF-m (Fig. 10).

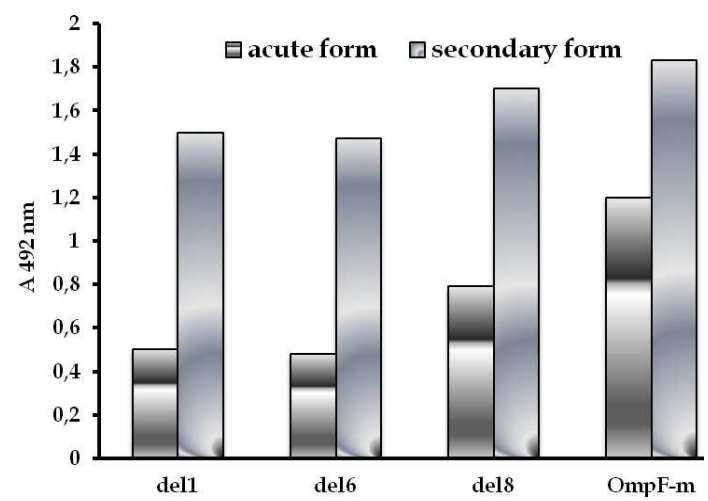

Fig. 10. ELISA of interaction of OmpF-m and mutant porins with specific antibodies in sera of patients with acute intestinal and second-hearth forms of pseudotuberculosis.

\section{Conclusion}

The recombinant porin (RP) of $Y$.pseudotuberculosis was obtained as a result of expression in E. coli cells. RP antigenic structure was shown to be partly similar to the structure of isolated $\mathrm{OmpF}$ in monomeric form (OmpF-m). RP was immunogenic for mice. Immunization of mice resulted in production of high-avidity antibodies to porin and stimulated bactericidal activity of peritoneal macrophages. Using site-directing mutagenesis, mutant porins with external loops deletions were also obtained. The external loops L1, L6, and L8 were not found to involve in the formation of antigenic determinants of RP. Nevertheless, the absence of L8 reduced the efficiency of interaction of del8 with antiserum to OmpF-m by $30-40 \%$. Probably, L8 is the part of the conformational determinants of OmpF-m formed at the level of tertiary and quaternary structure of porin.

Studies on antigenic properties and immunochemical activity of RP showed that the protein could be successfully used as diagnostic antigen to detect specific antibodies in the sera of patients with acute and secondary forms of pseudotuberculosis. In future, we plan to continue our work to create new vaccine preparations for animals and human on the basis of RP.

\section{Acknowledgement}

The authors are grateful to Mrs. Nataly Shepetova to helpful discussions and kind assistance in correcting the English version. 


\section{References}

Achouak,W., Heulin, T., \& Pages, J.M. (2001) Multiple facets of bacterial porins. FEMSMicrobiology Letters. Vol.99, pp.1-7.

Antonets, D.V., Bakulina, A.Y., Portnyagina, O.Y., Sidorova, O.V., Novikova, O.D., \& Maksyutov, A.Z. (2007) Prediction of antigenically active regions in the OmpF-like porin of Yersinia pseudotuberculosis. Dokl. Acad. Sci. (section Biochem Biophys). Vol.414, pp.124-6.

Arockiasamy, A., Kumar, P.D., Sundara Baalaji, N.,Rukmini, M.R., and Krishnaswamy, S.(2004) Folding and structural stability of OmpC from Salmonella typhi: Role of LPS and environment Curr. Science.Vol. 87, pp. 197-202.

Elkins,C., Barkley, K.B., Carbonetti, N.H., Coimbre, H.J., \& Sparling, P.F. (1994) Immunobiology of purified recombinant outer membrane porin protein I of Neisseria gonorrhoeae. Mol. Microbiol. Vol. 14, pp. 1059-1075.

Gordeets, A.V., Portnyagina, O.Yu., Vostrikova, O.P., Malashenkova, V.G., Beniova, S.N, Novikova, O.D., \& Solov'eva, T.F. (2000) The method of diagnosis of pseudotuberculosis. Patent. 2153172 Russian Federation № 98122085/14, Bull. No 20. p. 8 .

Guzev, K.V., Isaeva, M.P., Novikova, O.D., Solov'eva, T.F., \& Rasskazov, V.A. (2005) Molecular characteristics of OmpF-like porins from pathogenic Yersinia. Biochemistry (Mosc).Vol.70, No.10, pp.1104-1110.

Haltia,T., \& Freire, E. (1995) Forces and factors that contribute to the structural stability of membrane proteins. Biochim. Biophys. Acta, Vol. 1241, pp. 295-322.

Issaeva, M.P., Guzev, K.V., Novikova, O.D., Solovjeva, T.F., Degtyarev, S., \& Rasskazov, V.A. (2003) Porin from Yersinia pseudotuberculosis: cloning and analysis of primary structure. Adv Exp Med Biol. Vol. 529, pp. 257-260.

Likhatskaya, G.N., Solov'eva, T.F., Novikova, O.D., Issaeva, M.P., Gusev, K.V., Kryzhko, I.B., Trifonov, E.V., \& Nurminski, E.A. (2005) Homology models of the Yersinia pseudotuberculosis and Yersinia pestis general porins and comparative analysis of their functional and antigenic regions. J Biomol Struct Dyn. Vol. 23, No. 2, pp. 163-174.

Lupi, N., Bourgois, A., Bemadac, A., Laboucari, S., \& Pages J.-M. (1989) Immunological analysis of porin polymorphism in Escherichia coli outer membrane. Mol. Immunol, Vol. 26, pp. 1027-1036.

Menshikova, E.B., Zenkova, N.K., \& Shergin, S.M. (1994) Biochemistry of oxidative stress, SB RAMS, Novosibirsk.

Novikova, O.D., Frolova, G.M., Vakorina, T.I., Tarankova, Z.A., Glazunov, V.P., Solov'eva, T.F., and Ovodov, Yu.S. (1989) Conformational stability and immunochemical properties of yersinin--a basic protein of the outer membrane of the Pseudotuberculosis microbe Bioorg. Khim., 1989, vol. 15, pp. 763-772.

Peeters, C.C.A.M., Claassen, I.J.T.M., Schuller, M., Kersten, G.F.A., van der Voort, E.V.R., \& Poolman, J.T. (1999) Immunogenicity of various presentation forms of PorA outer membrane protein of Neisseria meningitidis in mice. Vaccine, Vol. 27, pp. 2702-2712.

Plekhova, N.G., Luba, L.M., Okhotin, S.V., Drobot, E.I., \& Goncharuk, Y.N. (2006) Metabolic activity of neutrophils at pseudotuberculosis infection. Zhurn. Microbiology, Vol. 3 (Appendix), pp. 43-47.

Portnyagina, O.Y., Novikova, O.D., Vostrikova, O.P., \& Solov'eva T.F. (1999) Dynamics of immune response to porin from outer membrane of Yersinia pseudotuberculosis. Bull. exp. Biol. med. Vol. 128, No. 10, pp. 437-440. 
Portnyagina, O.Y., Sidorova, O.V., Khomenko, V.A., Novikova, O.D., Vostrikova, O.P., \& Solovjeva, T.F. (2009) Immunogenic characteristics of recombinant OMPF-like porin from Yersinia pseudotuberculosis outer membrane. Bull Exp Biol Med. Vol. 148, No. 1, pp. 72-74.

Portnyagina, O.Y., Sidorova, O.V., Novikova, O.D., Vostrikova, O.P., Khomenko, V.A., \& Solov'eva, T.F. (2010) Immunochemical Characteristics of Synthetic Peptides with T_cellular and B_cellular Epitopes of Nonspecific Porins of Pathogenic Yersinia. Russian Journal of Bioorganic Chemistry. Vol. 36, No. 6, pp. 713-721.

Ranling, E.G., Martin, N.L., \& Hancock, R.E.W. (1995) Epitope mapping of the Pseudomonas aeruginosa major outer membrane porin protein OmpF. Infect. Immunol, Vol. 63, No. 1, pp. 38-42.

Ruleva, N.Y., Zvyagintsev, M.A., \& Dugin, S.F. (2007) Myeloperoxidase: biological functions and clinical implications. Modern high technologies. Vol. 8. pp.11-15.

Shaw, J., Grund, V., Durling, L., Crane, D., \& Caldwell H.D. (2002) Outer membrane protein antigen elicit a $\mathrm{CD} 4^{+}$-type 2 rather than type 1 immune response that is not protective. Infect. Immun, Vol. 70, No. 3, pp. 1097-1105.

Singh, S.P., Williams, Y.U., Benjamin, W.H., Klebba, P.E., \& Boyd D. (1996) Immunoprotection by monoclonal antibodies to the porins and lipopolysaccharide of Salmonella typhimurium. Microbial. Pathogenesis, Vol. 21, No. 4, pp. 249-263.

Somov, G.P., Pokrovsky, V.I., \& Besednova, N.N. (1990) Pseudotuberculosis, Meditsina, Moscow.

Supotnitsky, M. (1996) Protective properties of pore-forming proteins pathogenic bacteria. Bulletin of the Russian Academy of Medical Sciences, No. 8, pp. 18 - 22.

Timchenko, N.F., Novikova, O.D., Pavlov, G., Venediktov, V.S., \& Solov'eva, T.F. (1990) Protective properties of porin from the outer membrane of Yersinia pseudotuberculosis. Zhurn. Microbiology, Vol. 11, pp. 48-50.

Tseneva G.Y. (2006) Yersinia and yersiniosi, Medmassmedia, SPb.

Vermont, C. L., van Dijken, H.H., van Limpt, C. J., de Groot, R., van Alphen, L., \& van den Dobbelsteen G.P.J.M. (2002) Antibody avidity and immunoglobulin G isotipe distribution following immunization with a monovalent meningococcal $\mathrm{B}$ outer membrane vesicle vaccine. Infect. Immune, Vol. 70, pp. 584-590.

Vostrikova, O.P., Malashenkova, V.G., Novikova, O.D., Gordeets, A.V., \& Solov'eva, T.F. (2009) The outer membrane porin from Yersinia enterocolitica in yersiniosis diagnostics. Biochemistry (Moscow), Supplement Series A: Membrane and Cell Biology, Vol. 3, No. 4, pp. 438-446.

Vostrikova, O.P., Novikova, O.P., Drobkov, I.V., Darmov, I.V., Marakulin, I.V., \& Solov'eva, T.F. (2000) The immune response to the main pore-forming outer membrane protein Yersinia pseudotuberculosis in humans and laboratory animals. Immunology, No 795-V, pp. 15.

Wang, W., \& Malcolm, B. (1999) Two-Stage PCR Protocol Allowing Introduction of Multiple Mutations, Deletions and Insertions Using Quik Change Site-Directed Mutagenesis. BioTechniques, Vol. 26, pp. 680-682.

Wright, J.C., Williams, J.N., Christodoulides, M., \& Heckels, J.E. (2002) Immunization with the recombinant PorB outer membrane protein induced a bactericidal immune response against Neisseria meningitidisS. Infect. Immun. Vol. 70, No. 8, pp. 4028-4034. 


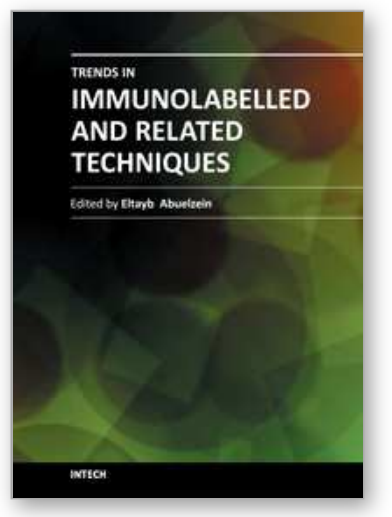

\author{
Trends in Immunolabelled and Related Techniques \\ Edited by Dr. Eltayb Abuelzein
}

ISBN 978-953-51-0570-1

Hard cover, 360 pages

Publisher InTech

Published online 27, April, 2012

Published in print edition April, 2012

The book is coined to provide a professional insight into the different trends of immunoassay and related techniques. It encompasses 22 chapters which are grouped into two sections. The first section consists of articles dealing with emerging uni-and-multiplex immunolabelled methods employed in the various areas of research. The second section includes review articles which introduce the researchers to some immunolabelled techniques which are of vital significance such as the use of the conjugates of the Staphylococcus aureus protein "A" and the Streptococcus Spps. protein "G" in immunolabelled assay systems, the use of bead-based assays and an overview on the laboratory assay systems. The book provides technological innovations that are expected to provide an efficient channel for developments in immunolabelled and related techniques. It is also most useful for researchers and post-graduate students, in all fields, where immunolabelled techniques are applicable.

\title{
How to reference
}

In order to correctly reference this scholarly work, feel free to copy and paste the following:

Olga Portnyagina, Olga Sidorova, Valentina Khomenko, Olga Novikova, Marina Issaeva and Tamara Solov'eva (2012). Immunochemical Properties of Recombinant Ompf Porin from Outer Membrane of Yersinia pseudotuberculosis, Trends in Immunolabelled and Related Techniques, Dr. Eltayb Abuelzein (Ed.), ISBN: 978-953-51-0570-1, InTech, Available from: http://www.intechopen.com/books/trends-in-immunolabelled-andrelated-techniques/immunochemical-properties-of-recombinant-omp-f-porin-from-outer-membrane-of-yersiniapseudotuberculo

\section{INTECH}

open science | open minds

\section{InTech Europe}

University Campus STeP Ri

Slavka Krautzeka 83/A

51000 Rijeka, Croatia

Phone: +385 (51) 770447

Fax: +385 (51) 686166

www.intechopen.com

\section{InTech China}

Unit 405, Office Block, Hotel Equatorial Shanghai

No.65, Yan An Road (West), Shanghai, 200040, China 中国上海市延安西路65号上海国际贵都大饭店办公楼 405 单元

Phone: +86-21-62489820

Fax: $+86-21-62489821$ 
(C) 2012 The Author(s). Licensee IntechOpen. This is an open access article distributed under the terms of the Creative Commons Attribution 3.0 License, which permits unrestricted use, distribution, and reproduction in any medium, provided the original work is properly cited. 